\title{
PENGARUH LAMA PENYIMPANAN TERHADAP KADAR VITAMIN C PADA BUAH PISANG MUSA ACUMINATE L (VARIETAS PISANG KEPOK) DAN PISANG MUSA PARADISIACA L KUNT VAR SAPIENTUM (VARIETAS PISANG AMBON
}

\author{
Nazudin', Ka'arina Sabban² \\ ${ }^{1,2}$ Program Studi Pendidikan Kimia, FKIP Universitas Pattimura
}

\begin{abstract}
ABSTRAK. Komponen gizi yang terdapat dalam musa acuminate dan musa paradisiaca salah satunya vitamin C. vitamin $\mathrm{C}$ berperan sebagai anti oksidan yang mengatasi radikal bebas yang merusak sel atau jaringan. Hasil penelitian menunjukan bahwa kadar vitamin $\mathrm{C}$ yang terdapat pada musa acuminate adalah $\mathrm{t}_{\mathrm{o}}=30,88 \mathrm{mg} / 100 \mathrm{~g}, \mathrm{t}_{2}=27,92 \mathrm{mg} / 100 \mathrm{~g}, \mathrm{t}_{4}=24,99 \mathrm{mg} / 100 \mathrm{~g}, \mathrm{t}_{6}=24,23 \mathrm{mg} / 100 \mathrm{~g}$, dan $\mathrm{t}_{8}=16,56 \mathrm{mg} / 100 \mathrm{~g}$. sedangkan untuk musa paradisiaca adalah $\mathrm{t}_{\mathrm{o}}=28,80 \mathrm{mg} / 100 \mathrm{~g}, \mathrm{t}_{2}=24,29 \mathrm{mg} / 100 \mathrm{~g}, \mathrm{t}_{4}=22,76 \mathrm{mg} / 100 \mathrm{~g}$, $\mathrm{t}_{6}$ $=22,68 \mathrm{mg} / 100 \mathrm{~g}$, dan $\mathrm{t}_{8}=19,22 \mathrm{mg} / 100 \mathrm{~g}$. Berdasarkan hasil penelitian kadar vitamin $\mathrm{C}$ pada musa acuminate dan musa paradisiaca selama penyimpanan mengalami penurunan.
\end{abstract}

Kata Kunci: musa acuminate dan musa paradisiaca Vitamin C, Spektrofotometri UV

\section{Pendahuluan}

Indonesia merupakan Negara tropis yang sangat subur bagi sebagian besar tanaman. Tanaman dapat dijadikan sebagai sumber bahan pangan. Pangan merupakan kebutuhan yang paling esensial bagi manusia untuk mempertahankan hidupnya e lam kehidupan sehari-hari. Pangan sebagai sumber zat gizi ( karbohidrat, lemak, protein, vitamin, mineral dan air ) yang menjadi landasan utama manusia untuk mencapai kesehatan dan kesejahteraan sepanjang siklus kehidupan. Melalui keanekaragaman pangan dapat dipenuhi kebutuhan zat gizi yang dibutuhkan oleh manusia ( Setyaningsih dkk, 2009),

Salah satu buah yang memiliki kandungan zat gizi yang tinggi yaitu buah pisang. Buah pisang merupakan buah yang mempunyai kandungan gizi sangat baik, antara lain dapat menyediakan energy dari karbohidrat cukup tinggi dibandingkan dengan buah-buahan lainnya. Buah [isang kaya mineral seperti kalium, magnesium, fosfor, besi dan kalsium. Buah pisang juga mengandung vitamin c , B kompleks, B6 dan serotonin yang aktif sebagai neurotransmitter dalam kelancaran fungsi otak ( Triyono, 2010 ' 1 )

Beberapa penelitian telah dilakukan mengenai pengolahan tepung dari berbagai jenis pisang menggunakan caara pengeringan matahari dan mesin pengeringan, kandungan vitamin $\mathrm{c}$ terlalu tinggi yang dihasilkan oleh pisang naangka yang bdijemur dengan cara konvesional $(97,35 \mathrm{mg} / 100 \mathrm{~g})$, sedangkan kandungan yang terendah dihasilkan oleh pisang kapok yaitu sebesar 47,8 mg/100g, (histifarina, dkk, 2012)

Berdasarkan beberapa hasil penelitian diatas maka perlu dilakukan penelitian pengaruh lama enyimpanan terhadap kandungan vitamin $\mathrm{C}$ varietas pisang ambon dan pisang kapok yang telah matang dan memiliki masa penyimpanan yang tidak terlalu lama sampai dengan tahapan konsumsi

\section{Metode}

\subsection{Alat-alat}

Timbangan analitik (ER-180A and), Spektrofotometer ultra-violet Apel PD-3000UV), peralat gelas (Iwaki Pyrek, kertas saring.

2.2. Bahan-bahan

Buah pisang ambon, buah pisang kapok, asam askorbat, aquabides.

\subsection{Preparasi sampel}

Sampel buah pisang ambon dan pisang kapok diambil langsung, buah pisang diupas dan diparut, kemudian sampel yang sudah halus ditimbang dengan teliti sebanyak 10 gram dicampur dengan aquabides san disaring. Fitratnya dimasukkan ke dalam labu takar $100 \mathrm{~mL}$ lalu ditambahkan aquabides sampai tanda batas yang sudah 
ditentukaan, kemudian dihomogenkan. Selanjutnya untuk masing-masing lama waktu penimpanan 2 hari, 4 hari, 6 hari, dan 8 hari dilakukan dengan cara yang sama.

\subsection{Pembuatan larutan standar vitamin $\mathrm{C}$}

Larutan standar vitamin c $100 \mathrm{ppm}$ dibuat dengan cara menimbang $10 \mathrm{mg}$ serbuk asam askorbat dan dilarutkan dengan aqubides sampai semua serbuk larut, kemudian dimasukan ke dalam labu takar $10 \mathrm{~mL}$ dan diencerkan dengan aquabides sa mpai tanda batas. Selanjtunya dibuat deret larutan standar vitamin c dengan konsentraasi $, 0,0,1,0,2,0,3,0,4.0,5,0,6,0,7,0$, dan 8,0, ppm. Untuk konsentrasi 0,0 ppm hanya digunakan blangko sedangkan untuk deretan standar $1,0,2,0,3,0,4,0,5,0,6,0,7,0$, dan $8,0 \mathrm{ppm}$ dibuat dengan cara mengambil 1,0, 2,0, 3,0, 4,0, 5,0, 6,0, 7,0, dan 8,0 mL dari larutan standar vitamin c 100 ppm kemudian diencerkan dalam labu takar $100 \mathrm{~mL}$ dengan aquabides hingga tanda batas.

\subsection{Penentuan Panjang Gelombang Maksimum}

Penentuan panjang gelombang maksimum, dipilih deret larutan standar dengan konsentrasi 8,0 ppm untuk digunakkan pada penentuan panjang gelombangmaksimum dengan interval panjang gelombang $260-270 \mathrm{~nm}$.

\subsection{Standar sampel}

Larutan standar vitamin c serta sampel buah pisang ambon dan pisang kapok yang telah dipreparasi diukur absorbansinya dengan menggunakkan spektrofotometer-UV, pengukuran absorbansi vitamin c pada panjang gelombang maksimum.

\subsection{Analisis Data}

Berdasarkan data hasil engukuran larutan standard dan larutan sampel, dbuat kurva standar untuk memperoleh hubungan antara absorbansi(y) dan konsentrasi (x).

Persamaan regresi dari hubungan antara absorbansi dan konsentrasi dapat digunakan persamaan sebagai berikut :

$$
\begin{aligned}
& \mathrm{Y}=\mathrm{ax}+\mathrm{b} \\
& \text { Dimana }: \mathrm{X}=\text { konsentrasi } \\
& \mathrm{Y}=\text { absorbansi } \\
& \mathrm{A}=\text { slop } \\
& \mathrm{B}=\text { intersep } \\
& \text { (Dewi, 2012:15) }
\end{aligned}
$$

Konsentrasi yang diperoleh dari kurva ini merupakan konsentrasi dalam satuan mg/L. sedangkan sampel yang digunakan untuk analisis kadarnya dalam $\mathrm{mg} / \mathrm{kg}$. untuk menghitung kadar vitamin $\mathrm{c}$ dari dalam satuan $\mathrm{mg} / \mathrm{kg}$ berat sampel dapat menggunakkan rumus sebagai berikut :

Konsentrasi $(\mathrm{mg} / \mathrm{L}) \mathrm{x}$ voume sampel $(\mathrm{L}) \mathrm{x}$ factor pengenceran

Kadar vitamin $\mathrm{c}(\mathrm{mg} / \mathrm{Kg})=$

$$
\text { Berat sampel }(\mathrm{Kg})
$$

(Pardede, dkk, $2013:$ 165)

\section{Hasil Penelitian}

\subsection{Panjang Gelombang Maksimum}

Analisis untuk mengetahui kadar vitamin c pada buah pisang kapok dan pisang ambon dengan menggunakan spektrofotometer ultra violet dengan panjang gelombang maksimum dimaksudkan agar meminimaliskan penyimpangan nilai pada pengukuran larutan analit. Vitamin c yang terlarut dalam air diketahui menyerap sinar ultra violet pada panjang gelombang $252 \mathrm{~nm}$, anderwulan 1992.

Pada penelitianini vitamin c yang terlarut dalam air diketahui menyerap sinar ultra violet pada panjang gelombang 262-263 nm, untuk penelitian vitamin pada buah pisang yang peniliti pakai adalah pada panjang gelombang $262 \mathrm{~nm}$. Pengukuran dilakukan secepat mungkin karena vitamin $\mathrm{C}$ dalam larutan mudah sekali mengalami kerusakan, (Anderwulan, 1992). Panjang gelombang yang digunakan kurang lebih sama dengan yang digunakan Karinda, dkk (2013) yang menganalisis kadar vitamin C pada Mangga Dodol menggunakan panjang gelombang $267 \mathrm{~nm}$, dan penelitian vitamin C dengan buah salak merah. Panjang gelombang tersebut berbeda dengan yang digunakan Oktoviana, dp kadarkk (2012) untuk mengetahui konsentrasi benzoate terhadap kadar vitamin $\mathrm{C}$ cabai merah, Panjang gelombang yang digunakan $510 \mathrm{~nm}$ perbedaan yang terjadi disebabkan oleh pelarut yang di gunakan berbeda. 


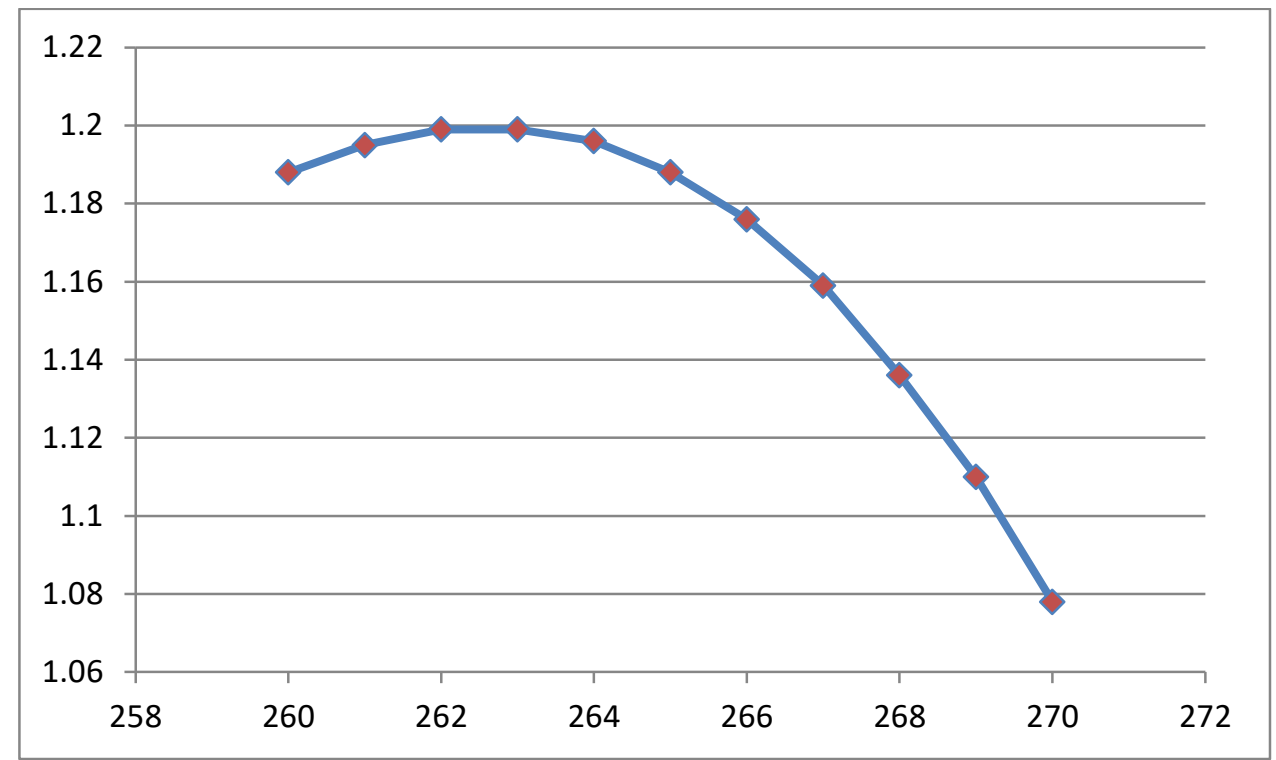

Gambar 1. Grafik panjang gelombang maksimum vitamin C

\subsection{Pengukuran Larutan Standar}

Berdasarkan data panjang gelombang maksimum yang diperoleh pada pengukuran sebelumnya (Lampiran 1), maka dibuat deret standar untuk membuat kurva kalibrasi larutan standar vitamin C. Kurva standar dibuat dengan cara mengukur absorbansi beberapa seri larutan standar, dengan cara ini interplorasi terhadap kurva standar maka dari pengukuran absorbansi sampel $\left(\mathrm{A}_{\mathrm{spl}}\right)$ dapat ditentukan konsentrasi saampel $\left(\mathrm{C}_{\mathrm{spl}}\right)$. Persamaan kurva standar dapat ditentukan dengan cara manual atau dengan cara program excel, sehingga untuk menghitung konsentrasi sampel digunakan persamaan linear yang didapat dari entri deata absorbansi dan konsentrasi (Sitorus, 2009). Kurva standar vitamin C yang diperoleh dapat dicantumkan pada Gambar 2.

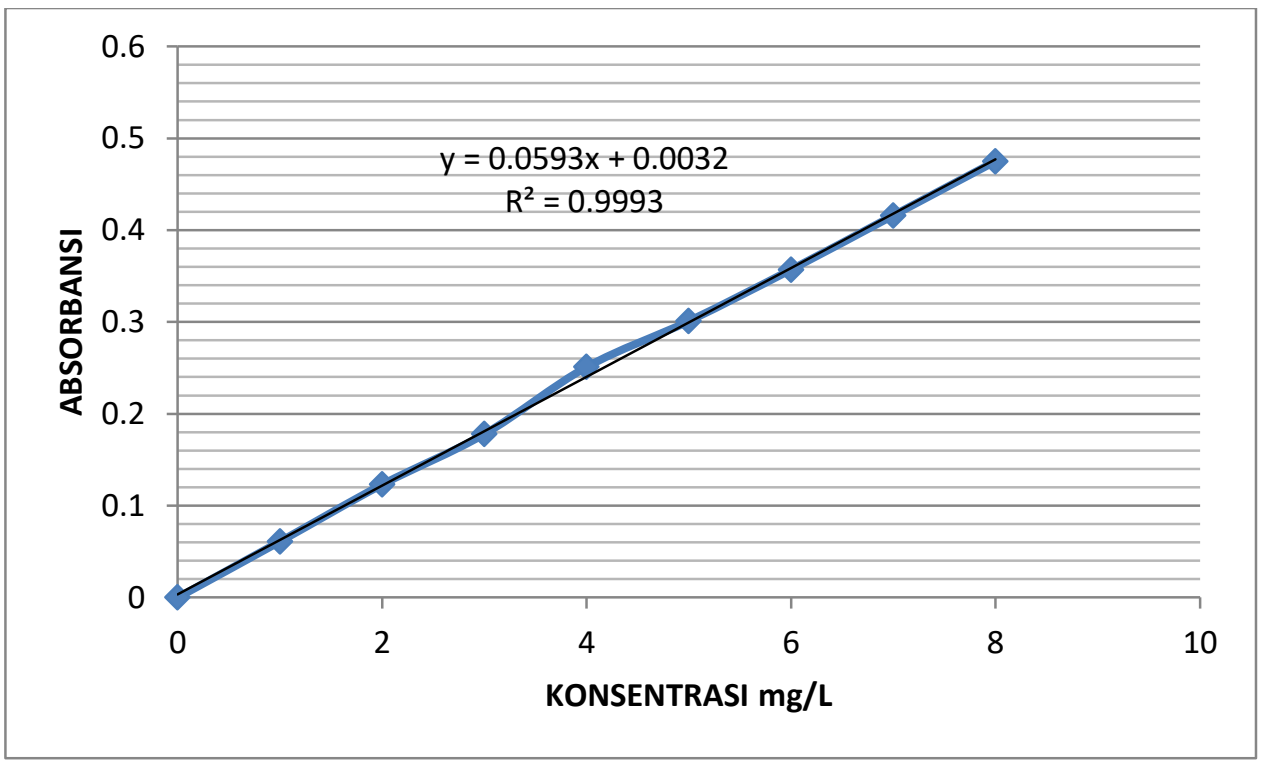

Gambar 2. Kurva Standar Vitamin C

Analisa kuantitatif dengan spektrofotometer sinar tampak (UV-Visibel) merupakan pengukuran sejumlah serapan elektromagnetik monokromatis pada panjang gelombang tertentu oleh sesuatu moekul atau zat kimia penyerap dimana nilai serapan sebanding dengan konsentrasi zat penyerap tersebut, pengukuran dilakukan pada 
daerah ultra violet yaitu $260-270 \mathrm{~nm}$. Spektrum ultra violet dan cahaya tampak suatu zat pada umumnya tidak mempunyai derajat spesifikasi tinggi, walaupun demikian spektrum tersebut sesuai untuk pemeriksaan kuantitatif (Departemen Kesehatan Republik Indonesia, 1995 dalam Musfiroh, dkk., 2009)

Prosedur dasar dalam analisa kuantitatif secara spektroskopi adalah membadingkan absorbansi energi radiasi pada suatu panjang gelombang tertentu oleh suatu larutan contoh terhadap suatu larutan standar (Sudarmadji, dkk., 1996). Dalam analisis kuantitatif menggunakan kurva baku. Analisis sampel menggunakan kurva baku (Gambar 2.6.) didasarkan pada kesesuain respon absorbansi yang dihasilkan oleh larutan baku (standar) dan sampel. Dalam analisis secara kuantitatif, pemilihan metode analisis tersebut perlu diperhatikan (Fatimah, 2003)

Dalam preparasi kurva standar perlu diperhatikan bahwa komposisi larutan standar sedapat mungkin dibuat mirip dengan komposisi larutan sampel. Karena pada larutan sampel selain terdapat zat yang akan dianalisa juga kemungkinan besar mengandung zat-zat yang bisa mengganggu. Pelarut yang digunakan tidak hanya melarutkan sampel dengan baik, tapi juga transparan pada daerah tempat dilakukan penentuan (Sudarmadji, dkk., 1996).

Kurva baku dibuat dengan cara mengukur absorbansi beberapa seri larutan standar. Dengan cara intrapolari terhadap kurva baku, maka dari pengukuran $\mathrm{A}_{\text {spl }}$ (absorbansi sampel) dapat ditentukan $\mathrm{C}_{\text {spl }}$ digunakan persamaan linear yang didapatkan dari entri data A (absorbansi) dan C (konsentrasi) (Sitorus, 2009).

Berdasarkan absorbansi larutan standar vitamin $\mathrm{C}$ yang berbeda pada konsentrasi vitamin $\mathrm{C}$ dengan panjang gelombang maksimum $262 \mathrm{~nm}$ diperoleh persamaan regresi yaitu y $=0,00593 \mathrm{x}+0,0032$ dengan koefisiean korelasi $\left(\mathrm{R}^{2}=0,9993\right)$.

\subsection{Persamaan Kadar Vitamin C}

Pisang merupakan buah yang baik untuk kesehatan karena banyak mengandung vitamin $\mathrm{C}$ yang membantu proses metabolisme dalam tubuh (Simorangkir, 1992). Ada penelitian ini sampel buah pisang yang digunakan adalah pisang kepok dan pisang ambon. Pada penentuan uji sampel dilakukan dengan cara, buah pisang disimpan pada suhu kamar selama dua, empat, enam dan delapan hari untuk mengetahui berapa banyak kandungan vitamin C pada lama penyimpanan. Buah pisang pada hari pertama pemetikan digunakan sebagai kontrol. Buah pisang dikupas kemudian diparut, untuk mengambil ekstrak, kemudian ditimbang sebanyak 10 gram, buah pisang yang sudah ditimbang diencerkan menggunakan aquabides, kemudian disaring agar mendapatkan filtrat. Filtrat yang diperoleh diukur dengan instrumen spektrofotometer ultra violet pada panjang gelombang $262 \mathrm{~nm}$.

Berdasarkan hasil pengukuran absorbansi pada setiap konsentrasi standar vitamin $\mathrm{C}$ dan pengukuran absorbansi pada tiap-tiap sampel untuk setiap pengulangan (Lampiran 3) dan cara perhitungan konsentrasi sampel berdasarkan regresi linier dari kurva standar dapat dilihat pada (Lampiran 4). Hasil pengukuran absorbansi pada setiap sampel dan perhitungan konsentrasi sampel untuk setiap pengulangan ditunjukan pada Gambar 3.

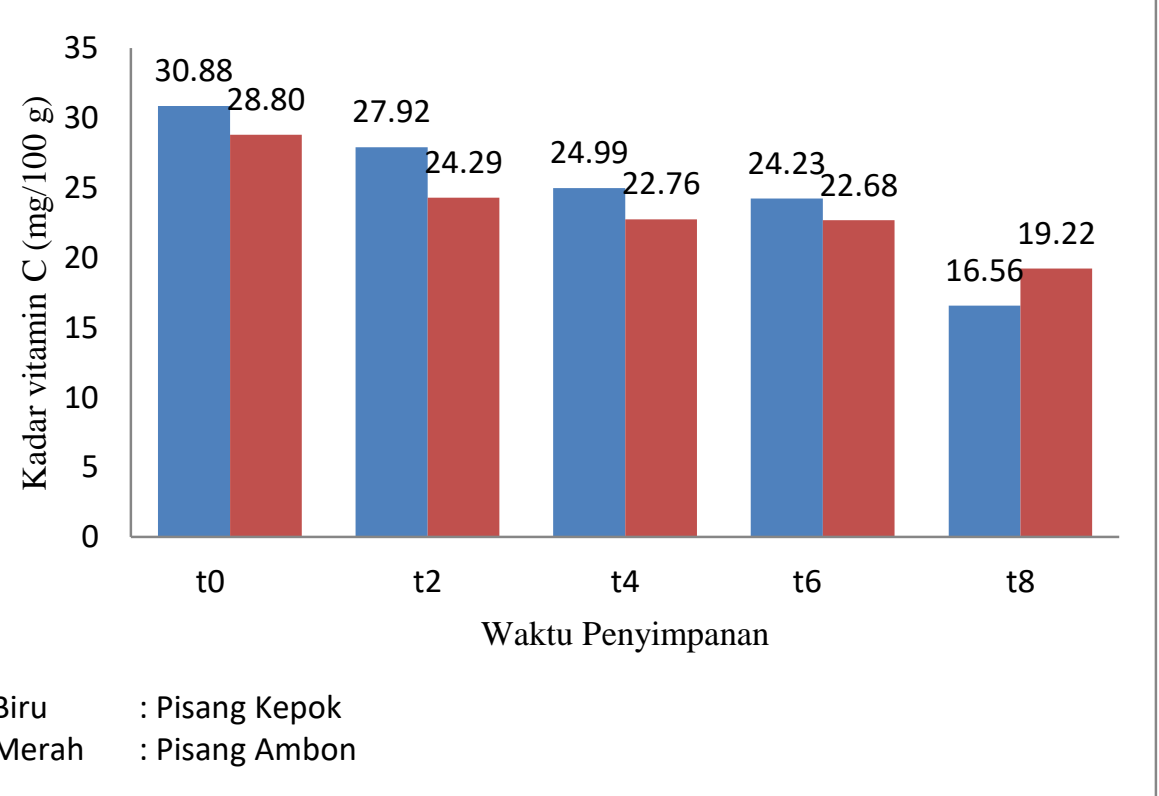

Gambar 3. diagram kadar vitamin C vs waktu penyimpanan sampel pisang kapok dan pisang ambon 
Berdasarkan hasil yang didapatkan pada sampel kontrol diketahui konsentrasi vitamin C rata-rata untuk pisang Kepok adalah 30,80 mg/100g dan pisang Ambon adalah 28,80 mg/100g. Konsentrasi vitamin C di kedua varietas pisang ini selanjutnya mengalami penurunan sejalan dengan lama penyimpanan hari ke-2, 4, 6, dan 8 kandungan vitamin $\mathrm{C}$ dalam buah pisang kepok berturut-turut sebesar 27,92 mg/100g, 24,70 mg/100g, 24,27 $\mathrm{mg} / 100 \mathrm{~g}$, dan $16,6 \mathrm{mg} / 100 \mathrm{~g}$. sementara di kandungan vitamin $\mathrm{C}$ dalam buah pisang ambon $\mathrm{mg} / 100 \mathrm{~g}$ untuk waktu penyimpanan yang sama adalah 24,29 mg/100g, 22,76 mg/100g, 22,68 mg/100g, dan 19,22 mg/100g. Berdasrkan data di atas diketahui presentasi penurunan konsentrasi larutan vitamin $\mathrm{C}$ adalah sebesar 9,58 \%, 20.01\%, 21,40\%, dan 46,40 \%. Pada buah pisang kepok yang disimpan selama 2, 4, 6, dan 8 hari. Sedangkan presentasi penurunan konsentrasi vitamin $\mathrm{C}$ adalah sebesar 15,66 \%, 20,97\%, 21,25\% dan 33,26\%. Pada buah pisang ambon yang disimpan dengan waktu yang sama. Dapat dilihat pada Gambar 4.

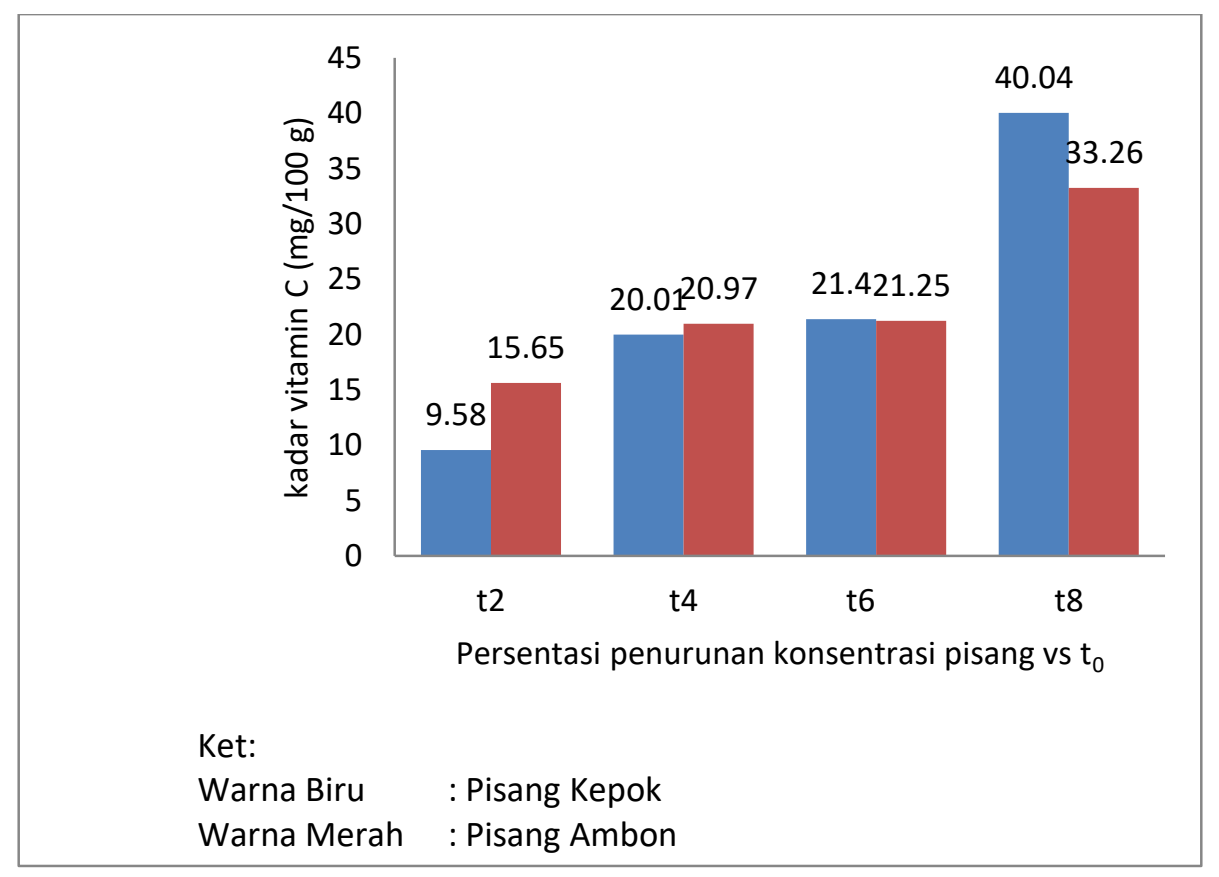

Gambar 4. persentasi penurunan konsentrasi vitamin dari $t_{2} \mathrm{~s} / \mathrm{d}$ terhadap $t_{0}$ pada pisang kapok dan pisang ambon

Hasil penelitian yang dilakukan terhadap buah pisang kepok dan pisang ambon dari desa poka, menyatakan bahwa nilai kadar vitamin $\mathrm{C}$ pada buah pisang saat kontrol lebih besar. Pada saat penyimpanan delapan hari kadar vitamin C-nya menurun. Hal ini sesuai dengan pendapat Andarwulan dan Koswara, (1992:43) dalam Utamai dkk, (2011:6) vitamin C akan mengalami penurunan apabila kita melakukan penyimpanan dalam waktu lama.

Buah pisang yang sejak dipetik pada saat buah belum matang sampai menjelang proses pematangan pada saat penyimpanan mengalami penurunan kadar vitamin $\mathrm{C}$ disebabkan oleh peristiwa respirasi di dalam buah yang tetap berlangsung, walaupun selama penyimpanan. Proses respirasi meningkatkan laju metabolisme, vitamin mengalami oksidasi sehingga terjadi penurunan kadar vitamin C (Wulandari, 2012: 26).

Menurut winarno (1993), vitamin C juga merupakan vitamin yang mudah rusak, selain dapat larut dalam air, vitamin $\mathrm{C}$ juga dapat hilang dalam proses oksidasi yang bisa dipercepat oleh adanya panas atau sinar matahari, enzim serta oleh katalis besi dan tembaga.

Asam askorbat bersifat sangat sensitif terhadap Laju respirasi buah dan sayur menentukan laju perubahan kearah penuaan, yang bermuara pada kebusukan yang ditandai dengan perubahan warna, tekstur, dan rasa. Penyimpanan buah-buahan pada kondisi yang menyebabkan kelayuan akan menurunkan kandungan vitamin $\mathrm{C}$ dengan cepat kaena adanya proses respirasi (Oktoviana dkk, 2012: 197). Aktivitas respirasi juga mengakibatkan padatan terlarut pada buah semakin besar yang disebabkan akumulasi gula hasil matabolisme pati. (Suhaidi, 2008).

Dalam penyimpangan bahan makanan yang mengandung vitamin $\mathrm{C}$ tertinggi, asam askorbat dan pengaruh luar penyebab kerusakan seperti suhu, oksigen, kadar air, dan katalisator logam. Asam askorbat mudah teroksidasi menjadi L- dehidroaskorbat yang masih mempunyai keaktifan sebagai vitamin C (Suhaidi, 2008: 47). Asam L- 
dehidroaskorbat secara kimia sangat labil dan dapat mengalami perubahan lebih lanjut menjadi asam Ldiketogulonat yang tidak memiliki keaktifan vitamin C (Pertiwi dan Susanto, 2014).

Buah pisang sebagai penunjang masyarakat, dimana buah pisang ini memiliki vitamin dan mineral yang sangat diperlukan oleh tubuh manusia untuk kelancaran metabolisme dalam proses pencernaan makanan, salah satu vitamin pada buah pisang adalah vitamin C. jika vitamin C dalam keadaan kering maka vitamin C akan benarbenar stabil akan tetapi dalam bentuk larutan seperti halnya dalam bahan pangan maka vitamin $\mathrm{C}$ bahan pangan tersebut tidak stabil, ini berarti bahwa rendahnya kadar vitamin $\mathrm{C}$ pada buah pisang selam penyimpanan.

Lama penyimpanan, menyebabkan kandungan vitamin $\mathrm{C}$ akan mengalami penurunan. Hal ini disebabkan karena tertundanya penguapan air yang menyebabkan struktur sel yang semula utuh menjadu kayu, dimana enzim askorbat oksidasi tidak disebabkan oleh sel, sehingga tidak mampu mengoksidasi vitamin $\mathrm{C}$ lebih lanjut menjadi senyawa yang tidak mempunyai aktifitas vitamin $\mathrm{C}$ lagi, tetapi apabila sel mengalami kelayuan maka vitamin $\mathrm{C}$ mengalami kerusakan (Oktaviana, dkk, 2012). Ini dikarenakan suhu yang rendah dapat menghambat respirasi dan aktifitas enzim yang sangat cepat, sehingga proses penguraian makromolekul terjadi dengan cepat yang akan terjadi kerusakan atau pembusukan.

Buah pisang kepok dan pisang ambon diamati setiap dua, empat, enam, delapan hari selama penyimpanan sehingga buah mengalami kerusakan dan tidak layak untuk dikonsumsi. Secara umum masyarakat mengiginkan buah pisang kepok dan pisang ambon yang masih tampak segar untuk dikonsumsi. Buah pisang jug bisa sebagai alternatif pengolahan buah pisang dimanfaatkan untuk sirup pisang, dodol pisang, selai pisang, ekstarak daging dan kulit buah pisang berfungsi sebagi anti diabetes.

\section{Kesimpulan}

Berdasarkan hasil penelitian yang di lakukan, bahwa ada sampel pisang ambon kontral kadar vitamin C sebesar 28,80 mg $\backslash 100 \mathrm{~g}$ pada penyimpanan selama 2 hari, kadar vitamin C pisang ambon sebesar 24,29 mg $\backslash 100$ $\mathrm{g}$, pada penyimpanan 4 hari kadar vitamin C 22,76 $\mathrm{mg} \backslash 100 \mathrm{~g}$, pada penyimpanan selama 6 hari terjadi penurunan kadar vitamin C menjadi 22,68 mg $\backslash 100 \mathrm{~g}$, dan pada lama penyimpanan selama 8 hari kadar vitamin pada buah pisang ambon sebesar 19,22 kg\100g.

Pada sampel pisang kapok kontrol juga kadar vitamin C sebesar $30.88 \mathrm{mg} \backslash 100 \mathrm{~g}$ pada penyimpanan salama 2 hari, kadar vitamin C pisang kapok sebesar $27.29 \mathrm{mg} \backslash 100 \mathrm{~g}$, pada penyimpanan 4 hari kadar vitamin C 24.70 $\mathrm{mg} \backslash 100 \mathrm{~g}$, pada penyimpanan selama 6 hari kadar vitamin C menjadi $24.27 \mathrm{~kg} \backslash 100 \mathrm{~g}$, dan pada lama penyimpanan selama 8 hari kadar vitamin pada buah pisang kapok terjadi penurunan kadar sebesar $16.66 \mathrm{~kg} \backslash 100 \mathrm{~g}$. semakin lama penyimpanan maka kadar vitamin $\mathrm{C}$ akan menurun.

\section{Daftar Pustaka}

Almatsier,S., (2003). prinsip dasar Ilm gizi. Gramedia Utama. Jakarta.

Andayani,R.,harun., S, dan maya., V , K. (2011). Penepatan kadar vitamin B1 pada beras merah tumbuk, beras merah giling, dan beras putih giling secara spektrofotometri UV-Visible, jurnal farmasi dan kesehatan, $1,7-11$.

Budiyati, C.S., dan Haryani, K. (2012). Pengaruh suhu terhadap kadar vitamin C pada pembuatan tepung tomat. Prosiding Seminar Nasional Rekayasa kimia dan Proses, 1-5.

Dewi, DC., (2012). Dereminasi kadar logam timbal (Pb) dalam makanan kaleng menggunakan destruksi basah dan dastruksi kering . jurnal alchemy, 2, 12-25

Fatimah, 1. 2003. Analisis fenol dalam sampel Air menggunakan s derifatis. Jurnal Logika, 9, 21-29, ISSN: 14102315. Yokyakarta : Uniservitas Islam Indonesia

Fatimah, S, Haryati, 1., dan jamaludin, A. (2009). Pengaruh uranium terhadap analisis thorium menggunakan spektrofotometer UV-Vis. Jurnal pusat teknolgi bahan bakar nuklir, 573-578.

Ginting, S U., (2011). Pola makanan dan minuman menuju budaya hidup sehat.. jurnal ilmu keolahragaan, 9, 5266.

Histifarina D, D. Musaddad, dan E. Murtiningsih. 2004. Teknik pengeringan dalam oven intuk Irisan wortel kering bermutu. Yokyakarta. Balai penelitian tanaman sayur. Jurnal Hortikiltura 14(2):107-112Silalahai, Jansen. 2006. Makanan Fungsional. Kinisius.

Huda, N., (2001).Periksaan kinerja spektrofotometer UV-Vis GBC911A menggunakan pewarna tartarzine CL 19140.. sikma epsilon, 20, 15-20. 
Karinda, M, Fatimawali., dan Citraningtyas, G. (2013). Perbandingan hasil penepatan kadar vitamin C mangga dodol dengan menggunakan metoda spektrofotometri UV-Vis dan iodometri. Junal ilmiah farmasi, 2 , 86-89.

Muchtadi, D., Plupi, N. S., dan Astawan, M. (1993). Metabolism zat Gisi Buku 1, Jakarta :pustaka Sinar Harapan.

Musfiroh,I.,Indriyani, W., Muchtaridi, dan Setiya, Y. 2009. Analisispenetapan kadar B-karoten dalam selai lembaran terung belanda (Cyphomandra betacea sendtn.) dengan metode spektrofotometrisinat tampak. Jurnal Program Kreatifitas Mahasiswa. Bandung: Univertitas Padjadjaran.

Muyasaroh, S., 2007. Pengaruh cara dan lama Pemeraman terhadap kadar Gula Reduksi dan kandunngan vitamin C pada buah pisang (musa Paradiasiaca.L) Kultivas Ambon Kuning. Jurusan Biologi, Fakultas Sains dan Teknologi Islam Negeri Malang. Malanng.

Oktoviana, Y, Aminah, S., dan Sakung, J. (2012). Pengaruh lama penyimpanan dan konsentrasi natrium benzoate terhadap kadar vitamin C, cabai merah (Capsicum annuum L). J. Akad. Kim, 1, 193-199.

Pardede, B. E., Adhitiyawarman, dan Arreneuz, S. (2013). Pemanfaatan enzim papain dari getah buah papaya (Carica Papaya L) dalam pembuatan keju cottage menggunakan bakteri Lactobacillus Bulgaricus. Jkk, $2,163-168$

Parengkuan, K., Fatimawali, dan Citraningtyas, G. (2013). Analisis kandungan merkuri pada krim pemutih yang beredar di kota manado. Jurnal Ilmiah farmasi-UNSRAT, 2, 62-68.

Pertiwi, E, F, D., dan Susanto, W,H. (2014). Pengaruh proporsi (buah:sukrosa) dan lama osmosis terhadap kualitas sari buah stroberi (Fragaria vesca L). Jurnal pangan dan agroindustry, 2, 82-90.

Purwoko, B,S dan Gunadi,. S. (1995). Pengaruh kosentrasi dan lama perlakuan Purwoko putresin terhadap perubahan kualitas buah pisang ambon. Jurnal bud.Agron, 23, 10-21.

Rahayu, E. S., dan pribadi, p. (20012). Kadar vitamin dan mineral dalam buah segar dan manisan basah karika dieng (Carica Pubescens Lenne dan K.Koch). Jurnal biosantifika, 4, 49-97.

Roedyarto, 1997. Budidaya Pisang ambon. Cetakan 1. Surabaya : PT Trubus Agrisarana.

Setyaningsi, E., Perwani, E, dan Sarbini, D. (2009). Perbedaan kadar kalsium, albumin dan daya terima pada selai cakar ayam dan kulit pisang dengan variasi perbandingan kulit pisang yang berbeda. Jurnal kesehatan, 2, 27-37. 